\title{
Analysis of Financial Statements to Assess Financial Performance of Cooperative Loan in Gianyar Regency
}

\author{
Eka Jayanti \\ \{info@warmadewa.ac.id \\ Universitas Warmadewa, Denpasar, Indonesia
}

\begin{abstract}
This research aims to determine the financial performance of the cooperative loan in cooperatives and Small Medium Enterprises of Gianyar Regency. The study used secondary data which were analyzed using descriptive qualitative analysis techniques. The results showed that the financial performance based on the liquidity or current ratio in KSP Prapen Mas, KSP KSP Eternity Funds and Sapta Ulakan Sari were not good. However, the solvency, represented with the Debt to Asset and the Debt to Equity ratios in KSP Prapen Mas, had a good performance from 2014 to 2016. KSP Sapta Funds Amerta had an outstanding performance while KSP Ulakan Sari performed dismally based on the Net Profit Margin, Return On Assets and Return On Equity. KSP Prapen Mas votes of NPM performed quite well, as shown by ROA. With excellent ROE, KSP Sapta Eternity Funds assessed from the NPM, ROA and ROE is good enough. Also, the KSP Ulakan Sari votes of NPM and ROA are quite good. In general, the performance of the cooperatives was not good enough.
\end{abstract}

Keywords: Financial performance, liquidity ratios, solvency ratio, ratio, the ratio of profittabilitas activity.

\section{Introduction}

Cooperatives as the perpetrator of the economy should be able to obtain the results of his efforts. A company or cooperative said healthy if the development of the results of his efforts increased so that cooperatives are able to improve the welfare of the members. Improved business results showed high levels of earning ratios of cooperatives, as well as business results otherwise getting down or even suffered losses showed low levels of survivability. These conditions demand a cooperative to improve and refine its business fields in order to compete with other cooperatives and defend the existence of cooperatives on an ongoing basis.

The cooperative has a wide range of activities in his business, but financial activity is one of the important activities in the cooperative. A financial cooperative with regards to the management of the use of funds and management of the resources of the Fund. To find out the extent of the financial performance of cooperation to achieve the goal, then it is important to conduct an assessment of the financial report. In addition to knowing the financial performance, financial analysis can also help in planning, or determine the appropriate measures. The cooperative is a business entity that consists of a person or legal entity of cooperatives with underpinning its activities based on the principles of the cooperative movement as well as the 
people's economy which is based upon the principle of the family (Act No. 25 of the year 1992 article 1 paragraph 1). Understanding the cooperative has compatibility with the constitution 1945 Article 33 paragraph 1 stating that the economy is structured as a joint venture on the basis of the family. The principle of family reflects the existence of consciousness of the human conscience.

Financial report analysis is a method of knowing the capabilities of the performance of the company or business entity in analyzing whether or bad financial position of a company. According to (Cashmere, 2017) the financial report is a report that shows the company's current condition. The company's current condition is the State of the finances of the company on a certain date (for balance) and a certain period (to income statement). The purpose of the creation of financial reports in general are:

1. Provide information about the type and amount of assets.

2. Provide information about the type and amount of liabilities and capital.

3. Provide information about the type and amount of income.

4. Provide information on the amount of fees and the kinds of costs.

5. Provide information about the changes that happened to assets, liability and capital of the company.

Based on the data shown that the financial statements is the combination of the fact that has been noted (recorded fact), principles and habits in accounting (accounting convetion and postulate), personal opinions (a personal Judgement) (Kasmir, 2017).

Liquidity ratios or often referred to as the working capital ratio is a ratio used to measure how a company's liquidity. In other words, the liquidity ratio is useful to know the ability of firms in the finance and fulfill the obligations/debts at the time billed overdue (Kasmir, 2017). Solvency ratio is a ratio that shows how the company can manage a loan to gain an advantage and also be able to pay back his debts. This ratio measures the company's ability to fulfill obligations in the long-term. Companies that are not solvable is the company that total debts greater than the total of its assets (Fahmi, 2016).

The ratio of earning ratios is earnings comparisons against total assets as well as its capital, the ratio of earning ratios measure the effectiveness of the overall management is demonstrated by the large to the small level of profit earned about sales or investment (Fahmi, 2016). Cooperative financial performance assessment is a process that must be done to know the financial condition of the cooperative so that cooperatives can be spared from the adverse conditions - conditions in the future. Regulation of the Minister of cooperatives set up how to assess the financial performance of a cooperative that is the candy of cooperatives and SMEs RI No. 06/Per/M-KUKM/V/2006 of Penilian financial performance with Standard financial ratios such as Liquidity Ratios, Solvency, Profitability, and the ratio of activity.

Existing Loan cooperative in Gianyar Regency of 81 Cooperatives, there is only 3 Cooperative Loan that routinely produces financial statements in the form of a balance sheet and Reports business results from the Remaining years up to the year 20142016 to Dinas and Coop Micro small and medium enterprises of Gianyar Regency.

Furthermore, based on the background of the issue above, the aim of this research is to analyze the financial performance of the Cooperative Loan in Gianyar Regency years 20142016. 


\section{Method}

This research was conducted at the Office of the regional cooperatives and SMALL MEDIUM ENTERPRISES Agency of Gianyar Regency. The object of this research is the field of finance, in particular regarding the assessment of the financial performance report of keuanganTahun 2014-2016. According to (Sugiyono, 2017) population is a whole element that will be used as the region of generalization. Elements of the overall population is a subject that will be measured, that is the unit that investigated. In this area, the population is made up of generalizations: object/subject that has certain characteristics and quantity specified by research to be studied and then drawn the conclusion. In this study researcher using financial reports contained on the Annual Member meeting book (LAM.) located in the Department of Cooperatives and Small Medium Enterprises of Gianyar Regency. According to (Sugiyono, 2017) sample is part of a number and characteristic owned by the population. When a large population, and researchers may not learn all that there is on the population for instance because of lack of funds, manpower and time. Thus, researchers can use samples taken from the population. The sample in this research is the report of the Annual meeting of the members of the Cooperative Loan in Gianyar Regency who take shelter under the Department of cooperatives and SMALL MEDIUM ENTERPRISES in Financial Reports about Gianyar Regency which is in the Cooperative Loan. The criteria used in this study are:

a. Loan Cooperative who submit Annual Work Meeting Report (RAT) to the Department of cooperatives and SMALL MEDIUM ENTERPRISES in Gianyar Regency are routinely the year 2014-2016.

b. Loan Cooperative who take shelter under the Department of cooperatives and SMALL MEDIUM ENTERPRISES in Gianyar Regency that has made financial reports within 2014-2016.

The data used in this research is secondary data. The data used are 3 Savings and Loans Cooperatives which routinely deposit financial reports and are registered in the Department of Cooperatives and SMEs in Gianyar Regency in 2014-2016. To answer the above problem formulation, data analysis techniques used in this research is descriptive qualitative analysis techniques, namely by describing the financial performance of cooperatives in financial ratios Liquidity Ratios, which include Solvency, profitability, and the ratio of the activity of the year 2014, 2015 and 2016 with the guided Sweets of cooperatives and SMEs RI No. 06/Per/MKUKM/V/2006 of Penilian Cooperative financial performance Standards with financial ratios.

\section{Result And Discussion.}

\subsection{The liquidity Ratio Analysis}

Analysis of the liquidity ratio above will show the ability of cooperation in fulfilling the obligation that is due soon or is soon to be paid. Liquidity ratio analysis can be seen from the ratio, by comparing Current assets liabilities against lancer, from the results of the analysis are obtained as follows: 
Table 1. Result Analysis of Current Ratio

\begin{tabular}{lccc}
\hline & Year & $C R(\%)$ & Category \\
\hline KSP Prapen Mas & 2014 & 199 & Good \\
& 2015 & 200 & Good \\
\multirow{3}{*}{ KSP Sapta Dana Amerta } & 2016 & 199 & Good \\
& 2014 & 193 & Good \\
& 2015 & 189 & Good \\
\cline { 2 - 3 } KSP Ulakan Sari & 2016 & 183 & Good \\
& 2014 & 117 & Lack \\
& 2015 & 128 & Lack \\
& 2016 & 139 & Lack \\
\hline
\end{tabular}

From the table it looks that the Current Ratio is owned by KSP KSP Mas Prapen and Sapta 2014 year of Eternity Funds up to the year 2016 are good, as are in the ratio group 175\% up to $200 \%$ with good categories, this means that both the cooperative It has a good ability in guarantee any debt smoothly owned with current assets available. While the KSP Ulakan Sari has a Current Ratio of years up to the year 20142016 is less well due to being in a group the ratio of $125 \%$ to $150 \%$ or $300 \%$ up to $325 \%$ with less good categories, this means that this cooperative have a less good ability in guarantee any debt smoothly owned with current assets available. This should get attention from KSP Ulakan Sari, because if there is a shortage of cash for example at the time when the customer wants to withdraw money from the cooperative, then it will make the image of co-operative being not good.

\subsection{Solvency Ratio Analysis}

Solvency ratio analysis can be used to measure how big the company is financed with debt. The use of too high a debt would harm the company because the company will be entered in the category extreme leverage (debt to extremes) that company stuck in debt levels are high, and it is difficult to release the burden of the debt. Therefore we recommend that companies have to balance how much debt a worthy taken and where the sources that can be used to pay debts. Solvency ratio used in this research is the Total Debt to Assets and Debt to Equity Ratio.

Table 2. Result Analysis of Debt to Asset Ratio and Debt to Equity Ratio

\begin{tabular}{lccccc}
\hline & Year & $\begin{array}{c}D A R \\
(\%)\end{array}$ & Category & $\begin{array}{c}D E R \\
(\%)\end{array}$ & Category \\
\hline KSP Prapen Mas & 2014 & 48,48 & Good & 138,7 & Enough \\
& 2015 & 48,11 & Good & 92,7 & Good \\
KSP Sapta Dana Amerta & 2016 & 44,03 & Good & 96,2 & Good \\
& 2014 & 51,22 & Enough & 105 & Enough \\
& 2015 & 52,17 & Enough & 109 & Enough \\
KSP Ulakan Sari & 2016 & 54,21 & Enough & 118,4 & Enough \\
& 2014 & 84,78 & Very lack & 574,5 & Very lack \\
& 2015 & 78,20 & Lack & 378,5 & Very lack \\
& 2016 & 71,93 & Lack & 256,3 & Very lack \\
\hline
\end{tabular}

Based on the chart, it looks that the Debt to Asset Ratio is owned by KSP Prapen Mas for the year 2014 up to 2016 are good, as are in the interval of $40 \%-50 \%$ which means that KSP Prapen Mas can guarantee all liabilities with total assets that owned by either. KSP Sapta Amerta Funds of the year up to the year 20162014 shows the Debt to Asset Ratio is in intervals of 50\%$60 \%$ that are included in the category; this means that the co-operative has a fairly good ability in guarantee obligations with the available assets. While the KSP Ulakan Sari has a Debt to 
Asset Ratio from the year 2014 to 2016 is less good, even in 2014 is very less because the ratio was above $80 \%$, this means that KSP Ulakan Sari use too high a debt that can because this cooperative is hard to get out of the use of funds from outside parties in the management of the cooperative.

When viewed from the side of the Debt to Equity Ratio, indicates the position of the KSP Prapen Mas for the year 2014 is in quite good condition, because there is more in the range of $70 \%$ to $100 \%$, and shows an increase for the year 2015 until 2016 with both categories, because it is in the range less than or equal to $70 \%$ which means that KSP Prapen Mas condition getting better the more the use of its own (private equity) in financing its assets. KSP Sapta Amerta Funds of the year up to the year 20162014 shows the Debt to Equity Ratio is in the interval of more than $100 \%-150 \%$ is included in the category simply, this means that this cooperative has enough ability in fund assets with its own capital. While the KSP Ulakan Sari has a Debt to Equity Ratio from the year 2014 to 2016 is very less, since the ratio was above $200 \%$, this means that KSP Ulakan Sari uses its own capital which is too small to finance its assets. But if we look at the changes from year to the year 20162014 shows the condition of the increasingly improved. Long-term creditors generally prefer Debt to Equity Ratioyang figure is small, because the smaller the ratio this means the greater amount of assets funded by the owner of the company and the greater the buffer the risk of the lender.

\subsection{Analysis of the Ratio of Earning Ratios}

Table 3. Result Analysis of Net Profit Margin, Return on Asset and Return on Equity

\begin{tabular}{|c|c|c|c|c|c|}
\hline & Year & $\begin{array}{c}\text { NPM } \\
\text { (\%) }\end{array}$ & Category & $\begin{array}{c}\text { ROA } \\
\text { (\%) }\end{array}$ & Category \\
\hline \multirow[t]{3}{*}{ KSP Prapen Mas } & 2014 & 8,86 & Enough & 7,93 & Good \\
\hline & 2015 & 8,04 & Enough & 7,38 & Good \\
\hline & 2016 & 9,82 & Enough & 9,2 & Good \\
\hline \multirow[t]{3}{*}{ KSP Sapta Dana Amerta } & 2014 & 6,97 & Enough & 5,84 & Enough \\
\hline & 2015 & 7,22 & Enough & 6,22 & Enough \\
\hline & 2016 & 7,34 & Enough & 6,37 & Enough \\
\hline \multirow[t]{4}{*}{ KSP Ulakan Sari } & 2014 & 4,77 & Lack & 4,18 & Enough \\
\hline & 2015 & 9,65 & Enough & 7,67 & Good \\
\hline & 2016 & 7,68 & Enough & 6,95 & Enough \\
\hline & Year & $\begin{array}{c}\text { ROE } \\
(\%)\end{array}$ & \multicolumn{2}{|c|}{ Category } & \\
\hline \multirow[t]{3}{*}{ KSP Prapen Mas } & 2014 & 22,67 & \multicolumn{2}{|c|}{ Very Good } & \\
\hline & 2015 & 21,10 & \multicolumn{2}{|c|}{ Very Good } & \\
\hline & 2016 & 18,06 & \multicolumn{2}{|c|}{ Good } & \\
\hline \multirow[t]{3}{*}{ KSP Sapta Dana Amerta } & 2014 & 11,96 & \multicolumn{2}{|c|}{ Enough } & \\
\hline & 2015 & 13,01 & \multicolumn{2}{|c|}{ Enough } & \\
\hline & 2016 & 13,92 & \multicolumn{2}{|c|}{ Enough } & \\
\hline \multirow[t]{3}{*}{ KSP Ulakan Sari } & 2014 & 28,31 & \multicolumn{2}{|c|}{ Very Good } & \\
\hline & 2015 & 37,13 & \multicolumn{2}{|c|}{ Very Good } & \\
\hline & 2016 & 24,76 & \multicolumn{2}{|c|}{ Very Good } & \\
\hline
\end{tabular}

Based on the table, it can be seen from the financial ratio performance earning ratios, as follows: Net Margin profit owned by KSP Mas Prapen and Sapta Funds Amerta from year up to the year 20142016 demonstrating a sufficient condition good, because it is in the range 5\% to $10 \%$ which means that the ability to generate profits from the volume of work done well enough. While the KSP Ulakan Sari for the year 2014 shows the ability to generate profit from work is done volume still less, but for the next years 2015 and 2016 began experiencing an 
increase and is in a category is good enough.If seen Return on Asset KSP Prapen Mas from the year 2014 to 2016 is in the category of good, because it is in the range of more than $7 \%$ to less than $10 \%$, meaning the ability of cooperation in utilizing its assets to generate profit is already good. While the KSP Eternity Funds and Sapta Ulakan Sari from the year 2014 to 2016 is in a group of more than 3\% to 7\% which shows good enough conditions, except in the year 2015 KSP Ulakan Sari is in good shape. When viewed from the Return On Equity, KSP Ulakan Mas Prapen and Cider from the year 2014 to 2016 is in a category of very good, because the value of the ratio is greater than or equal to $21 \%$, this indicates the ability to generate profit from equity (private equity) that is very good, except for the KSP Prapen Mas to year 2016 there are in that category, with the ratio is in the range of more than $15 \%$ to less than $21 \%$.

\subsection{Ratio Analysis Activity}

Table 4. Ratio Analysis Activity Total Assets Turnover

\begin{tabular}{lccc}
\hline & Tahun & TAT ( kali ) & Kategori \\
\hline KSP Prapen Mas & 2014 & 0,89 & Sangat Kurang \\
& 2015 & 0,92 & Sangat Kurang \\
\multirow{4}{*}{ KSP Sapta Dana Amerta } & 2016 & 0,94 & Sangat Kurang \\
& 2014 & 0,84 & Sangat Kurang \\
& 2015 & 0,86 & Sangat Kurang \\
KSP Ulakan Sari & 2016 & 0,87 & Sangat Kurang \\
& 2014 & 0,88 & Sangat Kurang \\
& 2015 & 0,79 & Sangat Kurang \\
& 2016 & 0,91 & Sangat Kurang \\
\hline
\end{tabular}

Based on the results of the analysis for the ratio of activity as in the table, can be explained as follows: KSP Prapen Mas, KSP KSP Eternity Funds and Sapta Ulakan Sari from the year 2014 to 2016 shows very less, since its assets turnover rate of less than 1 (one) time, which means that the cooperative ability assets and activity in generating sales (business volume) through the use of these assets is still very lacking.

\section{Conclusion}

Cooperative financial performance seen from the liquidity ratio current ratio, represented for KSP Prapen Mas, KSP Eternity Funds and Sapta Ulakan Sari from the year 2014 to 2016 showed conditions were unfavorable.The performance of financial solvency ratios as seen from cooperative represented by Debt to Asset Ratio and the Debt to Equity Ratio to KSP Prapen Mas, from 2014 to 2016 shows good performance, KSP Sapta Amerta Funds from the year 2014 to by the year 2016 shows a pretty good performance while the KSP Ulakan Sari from the year 2014 to 2016 still shows less good conditions even very less. Cooperative financial performance seen from the profitability or earning ratios represented by the Net Profit Margin, Return On Assets and Return On Equity, show that the financial performance of KSP Prapen Mas votes of NPM are quite good, judged from ROA well and judged from the ROE. Financial Kineja KSP Sapta Amerta Funds from the year 2014 to 2016 votes from the NPM, ROA, and ROE is quite well while financial performance of KSP Ulakan Sari years up to the year 20142016 votes of NPM and ROA are good enough and judged from the ROE very ba IK Financial performance ratios as seen from cooperative activities judged from Total Assets Turnover starting in 2014 to 2016 all cooperatives indicates performance is very less. 


\section{References}

Fahmi, I. (2016). Pengantar Manajemen Keuangan Teori Soal dan Jawab. Bandung: Alfabeta.

Indonesia Nomor 06/Per/Dep.6/IV/2016 Tentang Pedoman Penilaian Kesehatan Koperasi Simpan Pinjam dan Unit Simpan Pinjam Koperasi.

Kasmir. (2017). Analisis Laporan Keuangan. Jakarta: PT Rajagrafindo Persada.

Republik Indonesia. 1992. Undang-Undang Republik Indonesia nomor 25 Tahun 1992 tentang Perkoperasian

Peraturan Menteri Negara Koperasi dan Usaha Kecil dan Menengah Republik

Sugiyono. (2017). Metode Penelitian Bisnis. Bandung: Alfabeta. 